Entendo que este tipo de informação deveria ser colocado ao alcance de todas as pessoas, assim como dos legisladores, em uma linguagem acessível para não-médicos, a fim de que possam entender mais claramente sobre o que se está falando.

Em relação ao capítulo sobre criopreservação de conceptus, embora eu compartilhe a posição do Dr. Zegers no que diz respeito ao dano potencial que este processo de criopreservação poderia ter sobre os indivíduos e de sua posição sobre as taxas de sobrevida, considero que o artigo merecia mais ênfase sobre o dilema de casais e profissionais sobre o destino dos concepti não transferidos. Além disso, este deveria ser um assunto sobre o qual a sociedade e obviamente os legisladores deveriam ser ouvidos. Também as leis deveriam ser claras em relação a este tópico.

Finalmente, gostaria de comentar o capítulo que se refere à doação de gametos. A posição sobre a diferença entre a paternidade biológica e social me parece a mais acertada. Todos conhecemos as experiências bem-sucedidas entre pais que têm filhos adotivos, e na literatura médica está bem documentado o sucesso de pais que têm filhos pela doação de espermatozóides nos casos de azoospermia ou outras doenças. Existem estudos que mostram que, inclusive entre estes casais a incidência de divórcios é menor que na população em geral, talvez porque o projeto parental tenha sido mais difícil e mais discutido do que entre casais em geral. Em relação à ovo-doação, o número de crianças nascidas por esta variedade de doação de gametos é menor, por ser uma técnica recente, e conseqüentemente a informação disponível é mais restrita, mas aparentemente os resultados são similares aos de quando a célula doada é o espermatozóide.

Mas a doação de gametos de forma anônima, o nascimento de uma criança cujos pais biológicos são diferentes dos pais da criança, ou o nascimento de crianças geradas no útero de outra mulher diferente da que ofereceu o oócito, pode criar alguns problemas futuros que, no meu entender, não foram tocados no artigo. Provavelmente pelo escasso espaço de que o autor dispunha para tema tão complexo.

Considero que, quando falamos ou discutimos temas de doação ou adoção de gametos, não podemos esquecer que um dos direitos inalienáveis da pessoa humana é o de conhecer a sua origem. Embora seja difícil explicar que a origem é um espermatozóide ou um óvulo doado, anônimo, é necessário ter em conta experiências dolorosas sobre a mudança de identidade de crianças nascidas durante os re-

gimes militares na América Latina. Isto faz com que este tema da doação anônima seja discutido amplamente pela sociedade e claramente legislado, sobretudo tendo em conta assuntos futuros de filiação e herança.

\title{
O autor responde
}

The author replies Fernando
Zegers-Hochschild Agradezco las opiniones dadas por los comentaristas del artículo "Dilemas de la reproducción asistida”. Sin duda, las diversas posiciones expresadas en los comentarios contribuyen a una discusión pluralista y enriquezen al lector que por primera vez se enfrenta a reflexiones tales como el inicio de un individuo humano o la relación entre maternidad y progenitura. La tecnología reproductiva moderna no sólo ha contribuido a que muchas parejas puedan procrear, también ha contribuido a atraer en una discusión transdisciplinaria las más variadas formas del saber.

Uno de los elementos que ha generado mayor diversidad de opiniones es el momento en el desarrollo embriológico en que un individuo genéticamente único es considerado persona. La verdad es que esa discusión parece no tener fin, pero en lo que todos están de acuerdo es que un individuo humano nacido es una persona. Independientemente de si es capaz de expresar juicios racionales, morales o de tener conciencia de su propia existencia. El concepto de individuo humano en potencia o persona en potencia es el resultado de ser concientes de que nuestra existencia se da en una línea de tiempo que nos precede y de la cual no podemos prescindir. La discusión sobre cuando en el desarrollo embriológico somos persona no parece tan importante como decidir en que momento del desarrollo embriológico el proceso a ser persona y la substancia de dicho pro- 
ceso (el individuo humano) son merecedores de la misma forma de respeto. En cualquier etapa del desarrollo en que se sitúe esta condición, implicará que a ese individuo deben aplicarsele los principios de equidad, autonomía y no maleficencia, propios de las regulaciones éticas con que se relacionan las personas pertenecientes a una determinada sociedad. En consecuencia, el individuo humano en potencia deberá ser protegido como si fuese una persona nacida, por la ley y por los médicos responsables de su cuidado.

Si se acepta el principio que, en algún instante antes de nacer, el feto ya es acreedor de los privilegios propios de las personas nacidas, el momento en el desarrollo en que ese privilegio es adquirido obedece a convenciones difíciles de sustentar en forma objetiva y que varían mucho de una cultura a otra.

Desde que se establece la individualidad genética, se está frente a un ser humano en potencia que, a través de su desarrollo, no hace otra cosa que hacer cada vez más compleja su expresión génica, en la medida en que el tiempo, la diferenciación y la interacción con el medio así lo van determinando. Los criterios valorativos con que se le juzgue en relación a otros, por ejemplo, sus progenitores, serán los propios de cualquier juicio valórico utilizable entre personas de una determinada sociedad. El que mata en defensa propia es enjuiciado de manera diferente del que lo hace por placer. En ambos casos, el que mata ha hecho un juicio valórico que implica que su vida tiene más valor que la del otro, sin embargo, la valoración ética se aplica de manera diferente en ambas situaciones. De igual modo, el que a un embrión se le atribuya el carácter de persona en potencia no lo margina de los juicios valóricos a los que se exponen todos los miembros de un grupo social.

La discusión relativa al status del embrión pre implantacional será determinante en las regulaciones legales relativas a criopreservación, diagnóstico genético pre implantacional e investigación en embriones.

Respetando la diversidad existente en la aplicación del principio de no maleficencia, es mi creencia y la del grupo de trabajo al que pertenezco que el embrión humano debe ser protegido desde los primeros instantes de su existencia unicelular (cigoto). La manera de expresar dicho respeto es procurando por todos los medios con que cuenta la ciencia que éste continúe su desarrollo en su progenitora acorde a las potencialidades que le otorga su propia individualidad. Ello implica la transferencia al útero materno, ya sea en forma inmedia- ta o diferida por criopreservación. De lo anterior pueden desprenderse las siguientes conclusiones:

- Independientemente de la autorización otorgada por los progenitores, no deben efectuarse investigaciones en embriones pre implantacionales que no vayan en directo beneficio de ellos mismos o que generen riesgos para su futuro desarrollo.

- Al embrión pre implantacional debe respetarse (mientras esté al cuidado de terceros, los médicos), incluso por sobre la voluntad de sus progenitores. Ello significa que, aunque los progenitores expresen la voluntad de deshecharlos, el centro médico respetará su derecho a vivir.

- Los progenitores que han firmado consentimientos para criopreservación de embriones deben acceder a donarlos en caso que ellos no los deseen. El proceso de donación y adopción de embriones sigue un principio semejante a la adopción de personas nacidas. 